\title{
TINJAUAN REGULASI TOL LAUT BERDASARKAN TEORI REINVENTING GOVERNMENT
}

\author{
(Sea Toll Regulation Review Based on Reinventing Government Theory)
}

\author{
Ali Mashuda \\ Program Magister Ilmu Hukum, Fakultas Hukum Universitas Indonesia \\ JI. Salemba Raya No. 4 Jakarta 10430, JI. Prof. Mr. Djokosoetono, Kampus UI Depok 16424 \\ Email: for.alimashuda@gmail.com \\ Ade Irawan Taufik \\ Program Magister IImu Hukum, Fakultas Hukum Universitas Indonesia \\ JI. Salemba Raya No. 4 Jakarta 10430, Jl. Prof. Mr. Djokosoetono, Kampus UI Depok 16424 \\ Email: adeirawantaufik@gmail.com \\ Ridha Nurul Ihsan \\ Program Magister Ilmu Hukum, Fakultas Hukum Universitas Indonesia \\ JI. Salemba Raya No. 4 Jakarta 10430, Jl. Prof. Mr. Djokosoetono, Kampus UI Depok 16424 \\ Email: ihsanfay@gmail.com
}

Naskah diterima: 20 Juni 2019; revisi: 15 Agustus 2019; disetujui: 16 Agustus 2019

\begin{abstract}
Abstrak
Pemerintah sebagai penyelenggara negara harus mampu menjadi alat pendorong untuk melakukan reformasi birokrasi terhadap konsep pelayanan publik. Merancang reformasi birokrasi tidak sekedar menyederhanakan struktur birokrasi, tetapi mengubah pola pikir (mind set) dan pola budaya (cultural set) birokrasi untuk berbagi peran dengan peran aktor non-negara dalam tata kelola Pemerintahan yang baik. Oleh karena itu strategi Reinventing Government diaplikasikan di dalam birokrasi Pemerintah melalui pendekatan integral yakni menggabungkan pendekatan stuktural dan kultural. Untuk mengonfirmasi penerapan Reinventing Government di Indonesia, perlu ditelisik dari kebijakan yang diaplikasikan dalam hal ini Tol Laut. Bagaimana penerapan dan tantangan Reinventing Government dapat dilakukan melalui kebijakan Pemerintah dalam kebijakan Tol Laut tersebut dan bagaimana penerapan dan tantangan Reinventing Government dapat dilakukan dalam konteks Kebijakan Tol Laut oleh Pemerintah. Dengan menggunakan metode menggunakan pendekatan konsep secara normatif didapatkan kesimpulan Tol Laut telah menerapkan sebagian besar prinsip-prinsip Reinventing Government namun terdapat tarik menarik antara konsepsi peraturan dan misi. Tol Laut terlihat banyak digerakkan melalui peraturan dari pada oleh misi, sehingga diharapkan nantinya terdapat harmonisasi antara misi dengan peraturan.
\end{abstract}

Kata Kunci: reinventing government, tol laut, reformasi birokrasi, pelayanan publik

\begin{abstract}
The government as the organizer of the state must be able to become a driving tool for bureaucratic reform of the concept of public services. Designing bureaucratic reforms does not merely simplify bureaucratic structures, but changes mindset and cultural set of bureaucracy to share roles with the role of non-state actors in good governance. Therefore, the strategy of Reinventing Government is applied in the government bureaucracy through an integrated approach that combines structural and cultural approaches. To confirm the implementation of Reinventing Government in Indonesia, it is necessary to examine the policies applied in this case the Sea Toll Road. How the implementation and challenges of Reinventing Government can be done through government policies in the Sea Toll policy and how the implementation and challenges of Reinventing Government can be carried out in the context of the Sea Toll Policy by the Government. By using the method of using a normative concept approach, it was concluded that the sea highway has applied most of the principles of Reinventing Government, but there is a tug of war between the conception of regulations and mission. Sea tolls seem to be driven more by regulations than by missions, so it is hoped that there will be harmony between the mission and regulations. Keywords: reinventing government, sea highway, bureaucratic reform, public services
\end{abstract}




\section{A. Pendahuluan}

Nasionalisme merupakan pilar utama dalam berbangsa dan bernegara. Pemerintah termasuk organ penyelenggaranya harus memilikijiwa nasionalisme dalam memberikan pelayanan terbaik bagi rakyat. Oleh sebab itu, jiwa nasionalisme penyelenggara negara harus mampu menjadi alat pendorong bagi Pemerintah untuk melakukan reformasi birokrasi dengan mengubah konsep pelayanan publik. Reinventing Government adalah suatu usaha sadar dan terencana untuk mengubah struktur dan prosedur birokrasi (aspek reorganisasi atau institusional) dan sikap perilaku birokrat (aspek perilaku) guna meningkatkan efektivitas organisasi. ${ }^{1}$ Merancang reformasi birokrasi tidak sekedar menyederhanakan struktur birokrasi, ${ }^{2}$ tetapi mengubah pola pikir (mind set) dan pola budaya (cultural set) birokrasi untuk berbagi peran dengan peran aktor nonnegara dalam tata kelola pemerintahan yang baik. Oleh karena itu strategi Reinventing Government diaplikasikan di dalam birokrasi Pemerintah melalui pendekatan integral yakni menggabungkan pendekatan stuktural dan kultural.

Dalam demokratisasi ekonomi di Indonesia, Pemerintah bertugas untuk menjaga agar tujuan negara berjalan sesuai yang diamanatkan oleh konstitusi negara Indonesia. Peran Pemerintah diperlukan untuk menjaga keseimbangan antara para pemangku kepentingan terkait, yaitu masyarakat, Pemerintah dan swasta. Kewenangan negara dijalankan oleh pejabat Pemerintah (eksekutif). Mandat yang diberikan rakyat kepada negara meliputi perbuatan: 1) Kebijakan; 2) Pengurusan; 3) Pengaturan; 4) Pengelolaan; dan 5) Pengawasan. ${ }^{3}$

Sesuai dengan perkembangan konsep menjalankan pemerintahan, maka berkaitan dengan fungsi negara untuk menjaga ketertiban, memberikan kemakmuran dan memberikan layanan kepada masyarakat, maka ketersediaan regulasi dan aturan hukum dalam bidang pelayanan publik beserta bagaimana Pemerintah bertindak sebagai pelaksana pengendalian ketertiban umum atas pelayanan masyarakat, pada akhirnya memerlukan suatu cara pandang baru agar masyarakat turut dilibatkan dalam penciptaan pelayanan itu sendiri. Pada masa Orde Baru, Pemerintah bertindak sebagai pihak yang paling tahu terhadap semua yang dibutuhkan oleh masyarakat.

Pada perkembangannya, Pemerintah sendiri tidak lagi dapat bertindak sebagai pemerintahan yang otoritarian. Sebuah sistem sosial bagaimanapun harus berubah sesuai dengan perkembangan masyarakatnya, demikian juga pemerintahan Indonesia. Paradigma baru kemudian disosialisasikan bahwa Pemerintah harus berubah dalam mencapai tujuan negara, yaitu dengan Reinventing Government yang terdiri 
dari sepuluh prinsip, antara lain yaitu: ${ }^{4} 1$ ) pemerintahan katalis; 2) Pemerintah adalah milik rakyat; 3) pemerintahan yang kompetitif; 4) pemerintahan yang diarahkan oleh misi; 5) Pemerintah yang berorientasi pada hasil; 6) Pemerintah yang berorientasi pada pelanggan, bukan birokrasi; 7) Pemerintah dengan jiwa wirausaha; 8) Pemerintah yang antisipatif; 9) Pemerintah yang terdesentralisasi; 10) Pemerintah yang berorientasi pasar.

Beberapa pertimbangan perlunya suatu Reinventing Government menurut Osborne dan Gaebler antara lain adalah: 1) Pemerintah adalah suatu mekanisme dimana digunakan oleh masyarakat untuk membuat keputusan bersama (komunal); 2) Kepercayaan bahwa masyarakat sosial tidak akan dapat berfungsi secara efektif tanpa adanya Pemerintahan; 3) Kepercayaan bahwa orang yang bekerja pada pemerintahan bukanlah suatu masalah, sistem-lah yang membuat mereka bermasalah dalam bekerja; dan 4) Baik penganut liberalisme tradisional maupun konservatif lebih memiliki relevansi pada masalah-masalah yang dihadapi pemerintahan pada saat ini;

Reinventing Government dapat digunakan sebagai salah satu jalan keluar atas mandeknya reformasi birokrasi di Indonesia. Perubahan cara pandang ini pada akhirnya melahirkan dialektika-dialektika dalam masyarakat untuk menyusun dan menyepakati bersama bagaimana aturan main yang mencerminkan perlindungan hak warga negara. Sehingga Pemerintah tidak lagi bertindak otoritarian dan pengusaha serta masyarakat-pun bertindak dalam koridor etika yang benar. Hal itu tercermin dari beberapa model pengelolaan kebijakan dalam berbagai bidang. ${ }^{5}$

Untuk mengetahui penerapan Reinventing Government di Indonesia, perlu ditelisik dari kebijakan yang diterapkan. Salah satu yang menarik adalah kebijakan Tol Laut. Kebijakan ini telah berjalan kurang lebih 4 tahun. Kebijakan Tol Laut adalah salah satu contoh Pemerintah sebagai state actor berperan seperti wirausaha, karena kebijakan ini beranjak dari keinginan Pemerintah untuk memangkas biaya logistik setiap produk di Indonesia mencapai $24 \%$ dari produk domestik bruto. Oleh karena itu dalam tulisan ini akan dibahas bagaimana penerapan dan tantangan Reinventing Government dapat dilakukan melalui kebijakan Pemerintah dalam kebijakan Tol Laut tersebut serta bagaimana penerapan dan tantangan Reinventing Government dapat dilakukan dalam konteks Kebijakan Tol Laut oleh Pemerintah?

\section{B. Metode Penelitian}

Tulisan ini menggunakan pendekatan konsep secara normatif yang dianalisa secara kualitatif serta menggunakan studi kepustakaan sebagai frame tulisan. Tim Penulis berusaha menjelaskan konsep Reinventing Government berdasarkan atas informasi yang diperoleh dari literatur buku, tulisan ilmiah, jurnal, dan media massa atau bahan sekunder dihubungkan program Tol Laut Pemerintah sebagai variabel tunggal (mono variabel) sehingga dapat menghasilkan sebuah analisis serta kesimpulan mengenai

\footnotetext{
4 David Osborne \& Ted Gaebler. (1993), Reinventing Government: How The Entrepreneural Spirit is Transforming The Public Sector, (Plume), hlm. xviii-xix.

5 Erni Herawati, Op.Cit.
} 
Reinventing Government dalam penerapan program Tol Laut.

\section{Pembahasan}

\section{Teori Reinventing Government}

Reinventing Government adalah pemikiran yang cukup modern yang lahir atas koreksi dari perkembangan teori fungsi negara. Fungsi negara yang paling klasik adalah bertindak sebagaipenjagaketertiban (nachwachterstaat) yang dilandasi teori red light theory. Fungsi ini membatasi negara untuk campur tangan dalam pengelolaan negara. Kemudian fungsi negara berkembang menjadi lebih luas yakni memberikan kemakmuran kepada masyarakat (welfarestaat) yang dilandasi teori green light theory. Lalu berkembang lagi menjadi pelayan masyarakat (social service state). Pada tahap ini, organ negara justru menjadi sangat besar dan cenderung bergerak lambat dalam menjalankan fungsinya. Oleh sebab itu, munculah konsep Reinventing Government untuk kembali merampingkan negara namun tetap menjalankan fungsi menjaga ketertiban, memberikan kemakmuran, dan memberikan pelayanan. Hal itu dilakukan dengan cara yang berbeda dengan teori-teori sebelumnya, yakni dengan melakukan sharing job ke sektor privat dan masyarakat. ${ }^{6}$

Reinventing Government sebagaimana dikemukakan Osborne adalah teori yang berusaha menyuntikan semangat wirausaha ke dalam sistem administrasi negara. Birokrasi publik harus lebih menggunakan cara "steering" (mengarahkan) daripada "rowing" (mengayuh). Dengan cara "steering", Pemerintah tidak langsung bekerja memberikan pelayanan publik, melainkan sedapat mungkin menyerahkan ke masyarakat. Peran negara lebih sebagai fasilitator atau supervisor penyelenggaraan urusan publik. Model birokrasi yang hirarkisformalistis menjadi tidak lagi relevan untuk menjawab problem publik di era global. ${ }^{7}$

Reinventing Government atau wirausaha birokrasi, Pemerintah dengan bergaya wirausaha ini menjadi cara yang efisien dan efektif untuk menghindari kebangkrutan suatu birokrasi. Bagi Osborne dan Gaebler, organisasi birokrasi publik yang dijalankan berdasarkan peraturan tidak akan efektif dan kurang efisien, karena kinerjanya akan berjalan lamban dan terkesan bertele-tele. Namun, birokrasi yang digerakkan oleh misi sebagai tujuan dasarnya, akan lebih efektif dan efisien. Dengan mendudukkan misi organisasi sebagai tujuan, mereka dapat mengembangkan sistem anggaran dan peraturan sendiri yang memberi keleluasaan kepada karyawannya untuk mencapai misi organisasi tersebut. Osborne dan Gaebler memberikan posisi yang berhadapan antara misi dan peraturan dalam birokrasi organisasi publik. Birokrasi organisasi publik harus memilih salah satunya. Pilihan tersebut mengandung konsekuensi mengedepankan salah satu aspek akan mengabaikan aspek yang lain. ${ }^{8}$

Adanya peraturan dalam organisasi memang mempunyai tujuan yang baik, tetapi 
banyak kasus, hal tersebut menyebabkan organisasi berjalan lambat serta kurang mampu merespon tuntutan lingkungan yang berubah cepat. Dengan peraturan, orang tidak akan mampu melakukan apa yang menurut pandangannya benar, karena takut terkena sanksi jika ternyata ketahuan mengabaikan atau melanggar aturan tersebut. Oleh karena itu, mengapa banyak pegawai Pemerintah yang apatis dan tidak kreatif, serta melupakan misinya sebagai abdi negara dan abdi masyarakat. Menurut Osborne dan Gaebler karena adanya tarik menarik antara konsepsi peraturan dan misi. Peraturan memang dapat mencegah penyimpangan-penyimpangan dan korupsi, tetapi dengan pengorbanan terjadi pemborosan (inefisiensi). Keunggulan organisasi yang digerakkan misi, dibandingkan yang digerakkan oleh peraturan adalah lebih efisien, lebih efektif, lebih inovatif, lebih fleksibel serta akan mendorong semangat kerja yang lebih tinggi. ${ }^{9}$

Menurut Osborne dan Gaebler, mentransformasi semangat wirausaha kedalam sektor publik tidaklah mudah, karena birokrasi sudah terlanjur memiliki citra buruk dan sikap mental yang kurang terpuji. ${ }^{10}$ Sikap mental aparat birokrasi di Indonesia sebagian besar masih belum sesuai dengan tuntutan pembangunan. Masih nampak gejala sikap mental kurang bertanggungjawab, suka mencari jalan pintas, mengabaikan mutu, bergaya hidup mewah, dan suka meniru budaya hedonisme negara lain. Sikap tersebut justru akan menimbulkan etos kerja yang rendah dan produktivitas kerja yang rendah pula baik secara kualitas maupun kuantitas. Kalangan pegawai negeri atau aparat birokrasi masih dominan bermental priyayi yang tidak sesuai dengan fungsinya sebagai abdi masyarakat dan abdi negara. ${ }^{11}$

Reinventing Goverment tidak bisa terlepas dari paradigma New Public Management (NPM) yang muncul pada awal tahun 1980 dan menguat pada tahun 1990. Prinsip dasar teori ini adalah menjalankan administrasi negara sebagaimana menggerakkan sektor bisnis (run government like a business or market as solution to the ills in public sector). Strategi ini perlu dijalankan agar birokrasi model lama - yang lamban, kaku dan birokratis - siap menjawab tantangan era globalisasi. ${ }^{12}$

Dalam sejarah perkembanganya kemunculan NPM dapat dilihat dari reformasi birokrasi yang ada di Amerika pada tahun 1990-an yang digagas oleh Osborne dan Gaebler. Bahkan pada kurun waktu 4 tahun, yaitu tahun 1994 gagasan tersebut telah digunakan secara masif oleh negara-negara bagian di Amerika. Tercatat pada tahun-tahun pertama digagasnya pemikiran tersebut telah digunakan oleh gubernur Florida Lawton Chiles, gubernur Georgia Zen Miller yang mengubah sistem Pemerintahannya dan mengubah nama sistem tersebut menjadi "GeorgianGain", bahkan di Utah, Gubernur Michael Leavit mendistribusikan buku Osborne dan Gaebler pada anggota kabinetnya. ${ }^{13}$

9 Titik Djumiarti, Menggagas Strategi Reinventing Government dalam Memantapkan Kehidupan Berbangsa”,Op. Cit.

10 Miftah Thoha, Birokrasi Indonesia dalam Era Globalisasi, (Jakarta: PD Batang Gadis, 1996), hlm. 21.

11 Titik Djumiarti, Op.Cit.

12 Muhamad Rakhmat, Hukum Administrasi Negara Indonesia, diunduh melalui https://jurnal.unma.ac.id/index. php/RBJ/article/download/531/495, hlm. 34, (diakses pada 10 Desember 2018).

13 Jeffrey L. Brudney, Deil S. Wright, Revisiting Administrative Reform in the American States: The Status of Reinventing Government During the 1990s, Public Administration Review, Vol. 62/No. 3/2002, hlm. 354. 
Masifnya pengaruh Reinventing Government tersebut pada tahun 1994 akhirnya diadopsi oleh 38 negara bagian di Amerika dan lebih dari 50 persen dari kepala agensi melaporkan telah menggunakan sistem Reinventing Government atau sistem yang hampir sama. ${ }^{14}$

\section{Tinjauan Terhadap Pengaturan dan Implementasi Tol Laut}

Saat ini transportasi angkutan laut domestik masih terpusat melayani wilayah yang memiliki aktifitas ekonomi tinggi yaitu di wilayah Barat Indonesia meskipun karakteristik kepulauan di wilayah Timur Indonesia telah menjadikan transportasi laut sebagai tulang punggung aktivitas pergerakannya saat ini. Konsep tersebut dikenal sebagai konsep pembangunan ship follow the trade dimana konsep tersebut memiliki daya ungkit yang tinggi terhadap percepatan pertumbuhan ekonomi nasional. ${ }^{15}$

Namun untuk mewujudkan pemerataan, diperlukan pembangunan dengan konsep ship promote the trade, dimana pembangunan konektivitas di wilayah Timur Indonesia diharapkan mampu meningkatkan aktivitas ekonomi dan perdagangannya. Pengembangan pelayanan transportasi laut sebagai tulang punggung distribusi logistik yang menghubungkan wilayah Barat dan Timur Indonesia diharapkan mampu menurunkan biaya logistik sehingga mempercepat pertumbuhan ekonomi disertai terwujudnya pemerataan. ${ }^{16}$

Tol Laut merupakan salah satu program yang dilakukan Pemerintah Indonesia dengan tujuan menekan kesenjangan harga atau mengurangi disparitas harga yang terjadi antara wilayah Barat Indonesia dengan wilayah Timur Indonesia dengan mengoptimalkan transportasi laut. Pelaksanaan Tol Laut dimulai dan dijalankan pada November 2015, Pemerintah menunjuk PT. Pelayaran Nasional Indonesia (PELNI) untuk menjalankan program Tol Laut tersebut untuk menyediakan kapal dengan sistem terjadwal dari wilayah barat ke wilayah timur Indonesia dan sebaliknya. ${ }^{17}$

Konsep Tol Laut ini juga untuk memperbaiki proses pengangkutan logistik di Indonesia yang saat ini sedang gencar diterapkan oleh masa kepemimpinan Joko Widodo. Sehingga diharapkan proses distribusi barang (terutama bahan pangan) di Indonesia menjadi semakin mudah. Kemudian, berdampak pada harga bahan pokok yang semakin merata di seluruh wilayah Indonesia. ${ }^{18}$

Dasar dari penyelenggaraan Tol Laut adalah Peraturan Presiden (Perpres) Nomor 106 Tahun 2015 tentang Penyelenggaraan Kewajiban Pelayanan Publik Untuk Angkutan Barang di Laut (Perpres Tol Laut) pada tanggal 1 Oktober 2015 lalu. Perpres Tol Laut tersebut

14 Jeffrey L. Brudney, Deil S, Wright, Privatization Across The American States: Assessing And Explaining The Scope of Contracting by State Administrative Agencies. Makalah yang disampaikan dalam Annual Meeting of the American Political Science Association (APSA) pada 30 Agustus-2 September, San Fransisco, California.

15 Direktorat Transportasi Kementerian PPN/Bappenas, Laporan Implementasi Tol Laut 2015, http:// nusantarainitiative.com/wp-content/uploads/2016/02/150915-Buku-Tol-Laut-bappenas.pdf, hlm 7 (diakses pada 19 April 2019).

16 Ibid.

17 Devi Destiani dan Liana Angelia Yanggana, Pelaksanaan Program Tol Laut PT Pelayaran Nasional Indonesia", Jurnal Manajemen Transportasi \& Logistik, Vol. 04/No. 02/Maret 2017, hlm 1.

18 Berita Logistik dan Transportasi Indonesia, Mengenal Pengertian, Konsep dan Manfaat Tol Laut Indonesia", https://kargo.tech/artikel/tol-laut/ (diakses pada 3 Juli 2019). 
diharapkan dapat melayani kebutuhan masyarakat bagian Timur Indonesia melalui penyediaan barang kebutuhan pokok, barang industri dan strategis lainnya dengan harga yang tidak jauh berbeda dengan harga barang di Indonesia bagian Barat, serta dapat meningkatkan pertumbuhan ekonomi daerah dan terwujudnya stabilitas nasional yang mantap dan dinamis.

Namun, dengan diberlakukannya Peraturan Presiden Nomor 106 Tahun 2015 belum sepenuhnya dapat mencapai target penurunan disparitas harga di daerah tertinggal, terpencil, terluar dan perbatasan. Tujuan dari adanya Tol Laut tersebut ditujukan untuk mengurangi disparitas harga bagi masyarakat serta untuk menjamin kelangsungan pelayanan penyelenggaraan angkutan barang ke daerah tertinggal, terpencil, terluar, dan perbatasan. ${ }^{19}$

Dalam Perpres Nomor 106 Tahun 2015, Pemerintah sebagai subjek yang memiliki kewajiban menyelenggarakan kewajiban pelayanan publik memberikan penugasan kepada PT. PELNI untuk melaksanakan penyelenggaraan angkutan barang di laut. ${ }^{20}$ Artinya dalam regulasi tersebut tidak mengatur ruang keterlibatan swasta untuk turut serta melaksanakan pelayanan publik dalam pelaksanaan Tol Laut, sehingga kompensasi atau subsidi yang diberikan kepada BUMN yang ditugaskan.
Sayangnya setelah Perpres Nomor 106 Tahun 2015 dijalankan hampir 2 tahun lamanya masih terdapat kekurangan dan ketidakefektifan seperti konsep dan pelaksanaan teknis, berdasarkan hasil penelitian dari Tim Kajian Pusat Penelitian Ekonomi Lembaga IImu Pengetahuan Indonesia (LIPI), pembangunan Tol Laut belum efektif dengan konsep dari pelabuhan ke pelabuhan atau lebih dikenal port to port. ${ }^{21}$ Berdasarkan penjelasan Peneliti Pusat Penilitian Ekonomi LIPI, Panky Tri Febiyansah konsep tersebut ternyata menyebabkan masih adanya disparitas harga terutama di daerah pedalaman dan pulau-pulau terpencil, sehingga manfaat hanya dirasakan oleh masyarakat sekitar pelabuhan saja. ${ }^{22}$

Berdasarkan evaluasi tersebut, Pemerintah kemudian menerbitkan Peraturan baru untuk mendorong tercapainya target yang tercantum pada RPJMN 2015-2019, yaitu dengan Peraturan Presiden Nomor 70 Tahun 2017 tentang Penyelenggaraan Kewajiban Pelayanan Publik Untuk Angkutan Dari dan Ke Daerah Tertinggal, Terpencil, Terluar dan Perbatasan. Perpres tersebut sekaligus mencabut Perpres Nomor 106 Tahun 2015 karena dianggap belum sepenuhnya mencapai target penurunan disparitas harga, hal tersebut dapat dibuktikan melalui konsideran Menimbang Perpres 70 Tahun 2017.23

19 Lihat Konsideran huruf a Perpres Nomor 106 Tahun 2015 tentang Penyelenggaraan Kewajiban Pelayanan Publik Untuk Angkutan Barang di Laut.

20 Lihat Pasal 4 ayat (1) dan (2) dan lihat juga Pasal 2 ayat (1) Perpres Nomor 106 Tahun 2015 tentang Penyelenggaraan Kewajiban Pelayanan Publik Untuk Angkutan Barang di Laut.

21 Tidak Efektif, Tol Laut Didorong tidak hanya berdimensi Port to Port, Artikel 29 Agustus 2017, http://lipi. go.id/berita/belum-efektif-tol-laut-didorong-tidak-hanya-berdimensi-port-to-port/18928 (diakses 12 Agustus 2019).

22 Ibid.

23 Lihat Konsideran Menimbang huruf b Perpres 70 Tahun 2017 tentang Penyelenggaraan Kewajiban Pelayanan Publik Untuk Angkutan Dari dan Ke Daerah Tertinggal, Terpencil, Terluar dan Perbatasan 
Untuk memenuhi capaian target yang telah ditetapkan dalam RPJMN, maka program Tol Laut dirasa tidak cukup hanya mengatur angkutan di laut saja dalam memenuhi kewajiban pelayanan publik. Maka, dalam Perpres 70 Tahun 2017 diatur penyelenggaraan pelayanan publik yang lebih terintegrasi untuk angkutan barang di laut, darat dan udara. ${ }^{24}$

Dengan adanya Perpres 70 Tahun 2017 tersebut, terdapat perbedaan yang cukup membawa perubahan kearah penciptaan kompetisi dalam berusaha. Usaha untuk melaksanakan kewajiban dalam pemenuhan pelayanan publik untuk angkutan barang di laut, semula diselenggarakan oleh Pemerintah yang pelaksanaannya ditugaskan kepada PT. PELNI dan BUMN lainnya. Sekarang sudah membuka keterlibatan swasta untuk ikut dalam pemilihan penyedia jasa lainnya atau mekanisme lelang, untuk terlibat dalam pelaksanaan Tol Laut berdasarkan ketentuan dalam Pasal 5 ayat (4) Perpres 70 Tahun 2017 yaitu: "Dalam hal terdapat keterbatasan armada, penyelenggaraan pelayanan publik untuk angkutan barang di laut sebagaimana dimaksud pada ayat (1), dapat dilakukan pemilihan penyedia jasa lainnya sesuai dengan ketentuan peraturan-perundangundangan di bidang pengadaan barang/jasa Pemerintah."

Meskipun mekanisme penugasan menjadi hal yang utama, dengan kata lain tidak sepenuhnya terbuka kepada swasta. Ketentuan tersebut cukup membawa angin segar terhadap perubahan cara pandang Pemerintah agar melibatkan pihak-pihak lain seperti swasta untuk turut serta dalam melaksanakan kewajiban pelayanan publik.

Tujuan dikeluarkannya Perpres Tol Laut merupakan bentuk komitmen Pemerintah untuk merealisasi konsep menjadi program nyata, agar dapat bermanfaat bagi masyarakat di daerah khususnya di wilayah Indonesia bagian timur dalam menjamin ketersediaan barang terutama barang pokok dan barang penting, dan mengurangi disparitas harga serta menjamin kelangsungan pelaksanaan angkutan barang.

Diakui bahwa pelaksanaan program Tol Laut belum maksimal. Pelayanan kapal Tol Laut belum sepenuhnya menjangkau daerah T3P (Terdepan, Tertinggal, Terluar dan Perbatasan). Penggunaan teknologi informasi dalam tata kelola operasional Tol Laut belum terdigitalisasi dalam sistem pelayanan pelabuhan. Muatan balik yang belum optimal, tercatat data realisasi muatan berangkat pada 2018 tercatat sebesar 229.565 ton dengan total 239 voyage. Sedangkan realisasi muatan balik hanya sebesar 5.502 ton. ${ }^{25}$

\section{Penerapan Reinventing Government dalam Kebijakan Tol Laut}

Pembaharuan pelaksanaan program haruslah disusun dengan rencana yang komprehensif, menyeluruh tidak sporadis dan parsialistik. Merancang konsep Tol Laut sesungguhnya bermakna merumuskan suatu model program yang dapat memperkuat kapasitas negara, melalui pendefinisian ulang dan lingkup intervensi Pemerintah.

Konsep Reinventing Government pada dasarnya representasi dari paradigma New

\footnotetext{
Lihat Pasal 2 ayat (2) Perpres 70 Tahun 2017 yang berbunyi: “Penyelenggaraan pelayanan publik sebagaimana dimaksud pada ayat (1) meliputi pelayan angkutan laut, angkutan darat, dan angkutan udara".

25 Ibid.
} 
Public Management (NPM) dimana dalam NPM, posisi Pemerintah dilihat sebagai perusahaan jasa modern yang terkadang melakukan persaingan dengan pihak swasta, tapi di lain pihak dalam bidang-bidang tertentu memonopoli layanan jasa, namun tetap dalam koridor memenuhi kewajiban memberikan pelayanan yang berkualitas secara maksimal pada masyarakat dalam hal ini pelaksanaan program Tol Laut. Dimana hadirnya Tol Laut tersebut memiliki misi khusus untuk memberikan manfaat bagi masyarakat untuk menikmati pemerataan harga pada kebutuhan pokoknya melalui pemangkasan rantai pasok distribusi logistik yang berhubungan dengan pengusahaan pelayanan jasa angkutan laut.

Pelayanan jasa angkutan laut tersebut tentu bersinggungan dengan usaha yang di jalankan oleh swasta atau sektor non Pemerintah, Oleh karena itu, penting untuk mengkonfirmasi mengenai 10 prinsip Reinventing Government dalam pelaksanaan program Pemerintah, khususnya Tol Laut sebagai bentuk pelayanan publik yang pelaksanaannya efisien dan terjadi pereduksian peran dan fungsi Pemerintah yang semula memonopoli semua bidang pelayanan publik dapat berbagi dengan swasta untuk memberikan pelayanan publik.

Berdasarkan sejarah tersebut ada beberapa poin penting mengapa Reinventing Government dapat diterima dan diterapkan secara sporadis yang tercermin dalam 10 prinsip reinventing government, yaitu: $:^{26}$

\section{a) Pemerintahan yang katalis}

Sebagaimana tersebut di awal tulisan, bahwa birokrasi publik lebih mengedepankan cara "steering" (mengarahkan) daripada "rowing" (mengayuh). Hal tersebut dikarenakan dalam perspektif bisnis menjadi hal yang tidak efektif apabila birokrasi yang menggunakan cara untuk menyelesaikan masalah dengan cara birokrasi yang dibuat dan dipekerjakan oleh pegawai negeri (civil servant) dan mereka juga yang menjalankan fungsi pelayanan publik. Hal tersebut akan menciptakan tidak fleksibelnya suatu birokrasi "...government needs to separate steering from rowing so that those who are steering have some flexibility."

Kebijakan Tol Laut sebagai bentuk pelayanan Publik dengan tujuan menekan disparitas harga kebutuhan pokok masyarakat indonesia, Pemerintah memposisikan dirinya tidak lagi sebagai Regulator sekaligus Operator. Meskipun dalam Regulasi pelaksanaan kebijakan Tol Laut ini Pemerintah menugaskan PT. PELNI sebagai operator yang mengelola tetapi juga tidak menutup keterlibatan swasta dalam pengelolaan Tol Laut tersebut. ${ }^{27}$

Hal tersebut dibuktikan dengan adanya ruang keterlibatan swasta untuk mengelola Tol Laut, dengan mekanisme yang diatur dalam ketentuan regulasi yaitu proses pengadaan barang/jasa atau mekanisme tender. ${ }^{28}$

Pemerintah sudah mampu memisahkan antara fungsi Pemerintah sebagai pengarah

\footnotetext{
26 David Osborne, Reinventing Government, Public Productivity and Management Review, Vol. 16/No. 4/1993, hlm. 352-356.

27 Agung DH, "Pemerintah Libatkan Swasta untuk kelola Tol Laut", https://tirto.id/Pemerintah-libatkan-swastauntuk-kelola-tol-laut-bWjS. (diakses pada 20 April 2019).

28 Lihat dalam Pasal 7 ayat (1) dan (2) Peraturan Menteri Perhubungan Nomor PM 4 Tahun 2018 Tentang Penyelenggaraan Kewajiban Pelayanan Publik untuk Angkutan Barang Laut .
} 
dan fungsi Pemerintah sebagai pelaksana. Namun, Pemerintah enterpreneurial lebih berkonsentrasi pada pembuatan kebijakankebijakan startegis bukan disibukkan oleh halhal teknis pelayanan.

\section{b) Pemerintahan yang kompetitif}

Prinsip ini menyuntikkan konsep kompetisi kedalam service delivery. Model yang lama akan menggunakan konsep monopoli, dan konsep modern adalah meningkatkan kualitas dan efektifitas melalui kompetisi untuk meningkatkan produktivitas. ${ }^{29}$ Contoh yang diberikan oleh Osborne adalah pada daerah Phoenix bagian Arizona pada tahun 1978 di mana manajer departemen pekerja publik memberikan insentif pada beberapa vendor untuk berkompetisi dalam pembersihan kota tersebut dan akhirnya dengan kompetisi yang disuntikkan kedalam pelayanan publik membuahkan hasil yang produktif dan efektif. ${ }^{30}$

Pengelolaan Tol Laut tidak dilakukan dengan cara monopoli oleh BUMN, konsep kompetisi dilakukan oleh Pemerintah agar proses pelayanan publik angkutan laut berjalan sesuai dengan tujuannya. Pemberian kompensasi ${ }^{31}$ dan ruang kepada swasta menunjukkan bahwa Pemerintah melalui program subsidinya tidak diberikan sepenuhnya kepada BUMN melainkan dibagi kepada swasta untuk berkompetisi dalam tender dan memberikan pelayanan yang bersaing.

Pemerintah harus mengembangkan kompetisi (persaingan) di antara BUMN, swasta, masyarakat dan organisasi non Pemerintah dalam mengadakan pelayanan publik Tol Laut berjalan lebih efisien dan membentuk lingkungan yang lebih inovatif.

\section{c) Pemerintahan yang diarahkan oleh misi (Mission-Driven)}

Menurut Osborne pada prinsip ini sejatinya Pemerintah didorong oleh dua hal yaitu; aturan (rules) dan anggaran (budget). Prinsip ini di dalam organisasi wirausaha akan beranjak pada pertanyaan "Apa misi kita? Apa tujuan kita?" dan memberikan hak seluas-luasnya pada manajer menentukan

“(1) Direktur Jenderal melakukan penilaian terhadap armada yang dioperasikan oleh PT. Pelayaran Nasional Indonesia (Persero) atau Badan Usaha Milik Negara lainnya di bidang angkutan laut sebagaimana dimaksud dalam Pasal 6 ayat (2) dan ayat (3) sebagai penyelenggara pelayanan ublic untuk angkutan barang di laut dengan mekanisme penugasan.

(2) Berdasarkan hasil evaluasi terhadap penilaian sebagaimana dimaksud pada ayat (1) apabila ditemukan adanya keterbatasan armada pada penyelenggaraan kewajiban pelayanan publik angkutan barang di laut, dapat dilakukan pemilihan penyedia jasa lainnya sesuai dengan ketentuan peraturan perundang-undangan di bidang pengadaan barang/jasa Pemerintah."

29 Ronald B. Cullen, Donald P. Cushman, "Transitions to Competitive Government Speed, Consensus, and Performance", (New York; State University of New York), hlm. 6.

Pemerintahan yang kompetitif dituntut untuk lebih proaktif dalam bekerja dalam perspektif kewirausahaan, kompetitifnya Pemerintah juga harus diimbangi dengan infrastruktur yang memadai seperti regulasi yang mendukung dan sumber pasar yang mudah dicapai dalam era globalisasi. Lihat lebih jelas mengenai competitive government di Amerika, Timothy J. Conlan, Competitive Government in The United States: Policy Promotions and Divided Party, Journal of Policy and Administration. Vol. 4/No. 4/1991..

30 David Osborne, Op.Cit. hlm. 352.

31 Lihat dalam Pasal 7 ayat (3) dan (4) Peraturan Menteri Perhubungan Nomor PM 4 Tahun 2018 Tentang Penyelenggaraan Kewajiban Pelayanan Publik untuk Angkutan Barang Laut. 
arah untuk mencapai tujuan tersebut. ${ }^{32}$ Pada sistem yang lama aturan yang dibuat adalah anggaran didistribusikan ke beberapa sektor dan anggaran harus dihabiskan dalam kurun waktu setahun dan apabila tidak habis maka akan dipotong pada anggaran selanjutnya. Inilah yang dimaksud sebagai aturan yang merujuk pada penghabisan anggaran yang sia-sia karena orientasi pada sebuah institusi adalah bagaimana cara menghabiskan anggaran tersebut agar tidak dipotong pada tahun selanjutnya. Sehingga pada pandangannya Osborne memberikan cara yang lebih efektif seperti "...empowering the manager and employees to design their own budgets enhanced motivation and creativity" yang akan dicocokkan dengan misi apa saja yang mau diraih oleh sebuah institusi.

Peningkatan konektivitas nasional untuk mencapai keseimbangan pembangunan yang dituangkan dalam Rencana Pembangunan Jangka Menengah Nasional (RPJMN) 20152019 menekankan pada terintegrasinya pembangunan Tol Laut untuk mewujudkan daya saing dan kedaulatan wilayah kepulauan Indonesia sebagai negara maritim, menunjang pertumbuhan sektor pariwisata, serta mempersempit kesenjangan wilayah. ${ }^{33}$

Orientasi Pemerintah dalam Tol Laut pada setiap badan Pemerintahan untuk mendapatkan misi yang jelas, kemudian memberikan kebebasan kepada lembaga tersebut mewujudkan misi tersebut dalam batasan-batasan legal yang tertuang dalam dokumen perencanaan yaitu RPJMN dan ketentuan-ketentuan yang mengatur Tol Laut.

\section{d) Pemerintah yang berorientasi pada hasil}

Prinsip ini mengedepankan akuntabilitas yang mengarah pada baiknya sebuah hasil. Peran Pemerintahlah yang memastikan hasil apa yang harus dicapai oleh agensi dan mengikat agensi dengan insentif atau rangsangan untuk mencapai hasil tersebut.

Moda transportasi laut sangat penting untuk dikembangkan, terutama untuk angkutan jarak jauh. Namun, masih terdapat permasalahan dimulai dari keterpurukan peran armada pelayaran nasional, dimana sekitar $50 \%$ dari angkutan kargo domestik sudah berusia lebih dari 25 tahun, sehingga secara tidak langsung mempengaruhi sektor perdagangan dan perekonomian. ${ }^{34}$

Selain itu, biaya ekonomi yang tinggi juga menyebabkan turunnya minat pengguna transportasi laut, terlebih kurangnya fasilitas prasarana bongkar muat di pelabuhan juga masih menjadi masalah di sektor ini. Dari aspek logistik untuk angkutan laut, terdapat permasalahan tidak efisiennya pengangkutan barang yang diangkut terutama untuk angkutan laut ke Indonesia bagian timur.

Oleh karena itu, diperlukan dukungan insentif fiskal maupun nonfiskal sehingga mampu menekan biaya transportasi dan logistik. Penyediaan Public Service Obligation (PSO) untuk angkutan barang

\footnotetext{
32 Pada faktanya strategi yang dibangun seluas-luasnya oleh pemimpin akan menimbulkan dampak meningkatnya pertumbuhan pada misi yang diberikan. Lihat Marta Maretich, Jed Emerson dkk, Governingfor Impact: Managing Mission-Driven Organizations Through Stages of Growth and Investment, Saïd Business SchoolResearch Papers, 2016, hlm. 6.

33 Direktorat Transportasi, Kementerian PPN/Bappenas, “Laporan Implementasi Tol Laut 2015”, Op.Cit, hlm. 38.

34 Ibid.
} 
disamping PSO angkutan penumpang yang selama ini ditugaskan pada PT. PELNI juga perlu direalisasikan. Selain itu, upaya regional balancing harus dilakukan melalui keseimbangan pembangunan konektivitas global dan nasional, perkotaan dan perdesaan, pusat-pusat pertumbuhan dan daerah tertinggal, serta pembangunan transportasi intra-pulau dan antar pulau. ${ }^{35}$

Produk-produk yang diangkut dengan menggunakan Tol Laut dan angkutan laut komersil tentu memiliki perbedaan harga, mengingat Tol Laut merupakan program subsidi Pemerintah.

Tabel 1 Contoh Perbandingan biaya angkut barang di laut dengan menggunakan angkutan laut komersil dan kapal Tol Laut ${ }^{36}$

\begin{tabular}{clcc}
\hline No. & \multicolumn{1}{c}{ Trayek } & Swasta & Tol Laut \\
\hline $\mathbf{1}$ & SBY-MERAUKE & 10-11 Juta & 5,9 Juta \\
\hline $\mathbf{2}$ & SBY-MANOKWARI & 11-13 Juta & 5,3 Juta \\
\hline $\mathbf{3}$ & SBY-KAIMANA & 11-12 Juta & 5,2 Juta \\
\hline $\mathbf{4}$ & SBY-TIMIKA & 10-11 Juta & 5,7 Juta \\
\hline $\mathbf{5}$ & SBY-FAKFAK & 10-11 Juta & 5,9 Juta \\
\hline
\end{tabular}

Sumber: Hasil Lapangan, Direktorat Jenderal Perhubungan Laut Kementerian Perhubungan RI, Wawancara dengan Bagian Tol Laut, Ibu Magdalena Laily, Jakarta, Juli 2017 dalam Elfrida R Gultom, Merefungsi Pengangkutan Laut Indonesia melalui Tol Laut untuk Pembangunan Ekonomi Indonesia Timur

Evaluasi tahun 2018 terkait implementasi Tol Laut membawa secercah harapan akan percepatan terwujudnya pembangunan inklusif yang berkeadilan, manfaat nyata telah dirasakan rakyat Indonesia khususnya di wilayah timur, indikator sederhana dapat dicermati dari telah terjadinya peningkatan mobilitas manusia, mobilitas barang, harga transportasi yang lebih murah, biaya logistik yang lebih murah yang membawa manfaat turunnya hargaharga diwilayah $3 \mathrm{~T}$ berkisar $20 \%$ sampai dengan $40 \%$.

Harga semen di wilayah Wamena, Papua turun berkisar $35 \%$, dari semula Rp 500.000 per sak menjadi Rp 300.000 per sak. Daerah Wasior harga beras turun $4 \%$, semen $8 \%$, besi $10 \%$ dan seng $9 \%$. Di Nusa Tenggara Timur (NTT) dampak penurunan disparitas harga cukup terasa dibanding Papua. Misalnya saja di Larantuka, penurunan harga kebutuhan pokok $5 \%$ hingga $15 \%$, disamping itu aktivitas ekonomi lokal mulai menggeliat dengan terjaminnya jalur transportasi membawa produk ikan basah ke Surabaya, sementara di Rote NTT terjadi penurunan harga kebutuhan pokok $6 \%$ Hingga $13 \% .{ }^{37}$

Dengan adanya PSO diharapkan pelaku usaha swasta juga mau ikut terlibat dalam menjangkau wilayah-wilayah yang terpencil dan terluar, dimana sebelumnya masih tidak banyak dijangkau oleh pengusaha pelayaran.

\section{e) Pemerintah yang berorientasi pada pelanggan.}

Prinsip ini mengisyaratkan bahwa memberikan semua pilihan dan memberikan hak seluas-luasnya bagi pelanggan untuk memilih penyedia servis (service provider) karena pelanggan memiliki kebutuhan yang 
berbeda, dan bagi provider harus memberikan pelayanan yang baik agar pelanggan tidak kabur (out of bussiness). ${ }^{38}$

Pemerintah memperlakukan masyarakat sebagai pelanggan yang harus diberi pelayanan dengan menetapkan standar pelayanan, memberi jaminan dan sebagainya. Pemerintah meredesain organisasinya untuk menyampaikan nilai maksimum kepada pelanggan yang harus diberikan pelayanan yang mereka inginkan.

Bagi masyarakat maupun badan usaha tentu memiliki pilihan penggunaan provider/ vendor jasa angkutan, yaitu dengan menggunakan jasa angkutan swasta/komersil atau dengan jasa Tol Laut. Dari sisi masyarakat sebagai end user tentu pilihan harga yang lebih rendah dengan kualitas yang sama yang akan mereka pilih, tentu Tol Lautlah yang menjadi pilihannya.

Pelanggan disini berdasarkan konsep pelayanan publik adalah masyarakat, orientasi dari program Tol Laut memang untuk memberikan pelayanan penyediaan logistik untuk kebutuhan dasar masyarakat di wilayah-wilayah yang jarang diminati oleh swasta. Sehingga dengan adanya program Tol Laut orientasi pelayanan semakin meningkat dengan keterlibatan swasta didalamnya.

\section{f) Pemerintahan yang berjiwa wirausaha}

Prinsip ini mengedepankan asas dalam pengembangan suatu kegiatan kewirausahaan yaitu prinsip lebih banyak mengambil (earning) daripada mengeluarkan atau menghabiskan (spending). ${ }^{39}$ Osborne dalam pandangannya bahwa 99.99 persen tenaga di dalam Pemerintahan difokuskan untuk menghabiskan uang ${ }^{40}$ dan hal tersebutlah yang harus diubah paradigma insentifnya, salah satunya adalah dengan memberikan penghargaan/uang yang ada pada anggaran dan memberikannya 15 persen pada pekerja yang memiliki gagasan yang baik dan mengimplementasikannya.

Pemerintah berusaha memfokuskan dirinya bukan sekedar untuk menghabiskan anggaran, tetapi juga menghasilkan nilai. Mengoptimalkan insentif seperti anggaran subsidi sebagai dana inovasi untuk mendorong para pimpinan badan Pemerintah untuk berpikir strategis guna mendapatkan dana operasional. Pada prinsip ini justru Pemerintah lebih banyak menghabiskan anggaran untuk memenuhi target penyerapan penggunaan anggaran subsidi, mereka dituntut untuk menghabiskan anggaran yang sudah di tetapkan, jika tidak dapat menghabiskan

38 Pemerintah dalam menjadikan masyarakat sebagai pelanggan, di mana prinsip fundamentaladalah memberikan servis terbaik yang ada dengan menganggap bahwa pelanggan adalah segalanya. Bahkan penerapan prinsip customer-drivengovernment ini dapat disesuaikan dengan memaksimalkan sosial media dan teknologi yang sekarang sedang berkembang. Contohnya penggunaan panggilan dengan nomor 911 di Amerika untuk memberikan servis terbaik bagi warga Amerika. Lihat Jane Wiseman, Customer-Driven Government: How To Listen, Learn, And Leverage Data For Service Delivery Improvement, paper yang dipublikasikan oleh Data-Smart City Solutions bekerja sama dengan ASH Center For Democratic Governance And Innovation, pada tahun 2016, hlm. 5-9. Bahkan ada beberapa poin yang harus diperhatikan mengenai masyarakat sebagai pelanggan yaitu; (i) kebutuhan yang selalu berkembang (ii) data dari pelanggan (iii) memaksimalkan teknologi. Aurelia Kloosterhof, Greg Schmid dkk, the consumer-driven organization strategies for transformations, (Institute for the future, 2003), hlm. 2.

39 Cotton M. Lindsay, A Theory Of Gevernment Enterprise, Journal of Political Eonomy, Vol. 84/No. 5/1976, hlm. 1062-1063.

40 David Osborne, Op.cit, hlm. 355. 
maka pemotongan anggaran untuk kedepan akan disesuaikan dan dilakukan pemangkasan anggaran bahkan pencabutan subsidi. ${ }^{41}$

Akan tetapi, dalam hal ini Pemerintah yang mampu menghadirkan kebijakan yang berorientasi pada warga negara. Kebijakan tersebut memiliki nilai strategis karena akan menghasilkan dividen yaitu berupa dukungan dari warga negara/masyarakat.

\section{g) Pemerintahan yang antisipatif}

Dalam rangka memberikan perlindungan kepada pekerja dan juga pelanggan maka pada prinsip ini menekankan bahwa mencegah lebih baik daripada mengobati (prevention rather than cure).

Pemerintah berpikir jauh ke depan dengan mencoba melakukan pencegahan timbulnya masalah. Mereka menggunakan perencanaan strategis, pemberian visi masa depan, dan berbagai metode untuk melihat masa depan sebagai bentuk pengembangan program Tol Laut.

Regulasi yang dibuat oleh Pemerintah dalam menjalankan program dan kebijakan Tol Laut merupakan langkah antisipatif, sebab aturan main (rule of the game) memiliki kepastian hukum. Mulai dari perencanaan, pelaksanaan, evaluasi, SOP, tarif dan penegakan sanksi diatur untuk mencegah terjadinya penyimpangan.

\section{h) Pemerintahan yang terdesentralisasi}

Prinsip selanjutnya adalah prinsip di mana pola komunikasi dari atasan menuju bawahan. Pada sebuah kegiatan kewirausahaan pola hierarki yang baik antara atasan dan tim yang berada dibawah menentukan baik atau buruk, tercapai atau tidak tercapainya sebuah tujuan dari agensi. ${ }^{42}$

Pemerintah mendorong wewenang dari pimpinan pusat Pemerintah melalui organisasi atau sistem, mendorong struktur vertikal langsung untuk melakukan pelayanan atau pelaksanaan dalam membuat sebuah keputusan. Hal tersebut dapat ditelisik melalui Perpres 70 tahun 2017.

Berdasarkan Peraturan Presiden Nomor 70 Tahun 2017 tentang Penyelenggaraan Kewajiban pelayanan publik untuk angkutan barang dari dan ke daerah tertinggal terpencil, terluar dan perbatasan dan Peraturan Presiden Nomor 71 Tahun 2017 tentang penetapan dan penyimpanan barang kebutuhan pokok dan barang penting. Kedua regulasi tersebut memberikan kewenangan kepada menteri yang menangani urusan perhubungan dan menteri yang mengurusi urusan perdagangan, dalam melaksanakan tugas dan kewenangannya tersebut menteri perlu memperhatikan masukan dari menteri lainnya dan Pemerintah Daerah.

${ }_{41}$ Lihat Harian Ekonomi Neraca, Tak Penuhi Target, Subsidi Tol Laut Terancam Dicabut, www.neraca.co.id/ article/108160/tak-penuhi-target-subsidi-tol-laut-terancam-dicabut (diakses 20 April 2019).

42 Majunya teknologi dan dengan diimbangi dengan pasar internasional akhirnya menempatkan Pemerintahan hanya sebagai institusi politik semata yang tidak bisa mengerjakan hal-hal yang terkait dengan bisnis maupun pertumbuhan ekonomi, karena globalisasi sendiri tidak hanya berdampak pada perubahan pada ide-ide tentang perekonomian namun juga persepsi terhadap Pemerintahan dan peran serta fungsi dari Pemerintah itu sendiri. Dennis A. Rondinelli, James H. Johnson Jr, dkk, "The Changingforces Of Urban Economic Development: Globalization And City Competitiveness,", The Journal of Policy Development and Research Vol. 3/No. 3/1998, hlm. 71-105. Lihat juga lebih dalam pada G. Shabbir Cheema, Dennis A. Rondinelli ed, Decentralizing Governance Emerging Concepts and Pratice, (Washington DC; Brookings Institutions, 2007). 


\section{i) Pemerintahan yang dimiliki oleh masyarakat}

Hal yang harus diperhatikan dalam prinsip ini adalah attitude dan actions ${ }^{43}$ dari dua perspektif yaitu dari masyarakat dan dari Pemerintah. Masyarakat tidak boleh selalu beranggapan bahwa sebagai masyarakat selalu ingin diberikan pelayanan (service oriented) karena dalam perspektif ini masyarakat akan tenggelam dalam kebiasaan konsumerisme dan bahkan hedonisme semata, sedangkan perspektif yang kedua, Pemerintah dalam hal ini disatu sisi memberikan pelayanan namun juga memberdayakan masyarakat untuk ikut serta dalam tujuan yang telah ditentukan (empowering than service).

Menjadikan masyarakat sebagai subyek pembangunan sekaligus memiliki wewenang kontrol, kewenangan tersebut yang dimiliki Pemerintah untuk dialihkan kepada masyarakat sebagai bentuk pemberdayaan agar masyarakat mampu mengontrol pelayanan yang dilakukan Pemerintah melalui Tol Laut.

Pemberian ruang masyarakat untuk terlibat dalam pemberian pelayanan sangat besar, misalnya keberadaan Badan Usaha Milik Desa Bersama sebagai kelembagaan ekonomi yang khas milik masyarakat memanfaatkan program yang sedang dijalankan Pemerintah yaitu Tol Laut. Badan Usaha Milik Desa Bersama menjadi operator penyaluran/pendistribusian bahan pokok untuk kebutuhan masyarakat di kawasan pedesaan wilayahnya dengan tepat sasaran.

\section{j) Pemerintahan yang berorientasi pada pasar (market-oriented)}

Prinsip yang terakhir adalah prinsip yang mengedepankan pada cara untuk mencapai sebuah hasil dari agensi. Hal tersebut berorientasi pada prosedur yang digunakan, yaitu bukan dengan menggunakan prosedur secara administratif yang terlalu lama dan tidak fleksibel namun dengan menggunakan metode insentif untuk menciptakan kreatifitas dan efisiensi dalam mencapai tujuan dari sebuah agensi.

Pemerintah sering memanfaatkan struktur pasar swasta untuk memecah masalah daripada menggunakan mekanisme administratif, seperti memanfaatkan peraturan untuk menyampaikan pelayanan atau perintah dan kontrol. Menciptakan insentif keuangan atau subsidi, insentif pajak, pajak hijau, dan sebagainya. Organisasi swasta atau anggota masyarakat mengorientasikan perilaku pemecahan masalah.

Program Tol Laut yang dijalankan Pemerintah dengan melibatkan BUMN, swasta serta dengan pemberdayaan masyarakat melalui Badan Usaha Milik Desa Bersama akan berjalan lebih efektif dan efisien, bahan pokok yang dibutuhkan masyarakat akan tersalurkan dengan tepat dan memutus mata rantai birokrasi serta tengkulak dan pengusaha yang membuat masyarakat kerap kali tidak menikmati manfaat program yang menjadi kebijakan Pemerintah.

Prinsip-prinsip tersebut secara kumulatif menjadi hal yang paling mendasar dalam reformasi birokrasi di dalam tatanan Pemerintahan yang tujuannya adalah

43 Richard C. Kearney, Barry M. Feldman, dkk, Reinventing Government: City Manager Attitudes and Actions, Public Administration Review, Vol. 60/No. 6/2000, hlm. 537. 
mengubah secara fundamental hal-hal yang dapat membuat sebuah birokrasi yang tidak fleksibel, tidak memiliki tujuan yang jelas, dan yang paling penting adalah prinsipprinsip tersebut adalah berdasarkan pada untung rugi yang didapatkan oleh masyarakat dan Pemerintah. Prinsip yang sebenarnya bukan pada ranahnya inilah yang menjadi pertanyaan yang sangat mendasar apakah Reinventing Government yang merupakan bussiness-oriented dapat diterapkan pada sistem birokrasi yang ada pada Pemerintahan.

Untuk itulah dalam pandangannya Osborne memberikan langkah-langkah bagaimana prinsip-prinsip yang berorientasi pada sistem kewirausahaan dapat diterapkan pada sebuah Pemerintahan, yaitu:44 "a) Set the price of government; b) Set the priorities of government; c) Set the price of each priority; d) Develop a purchasing plan for each priority; e) Solicit offers to deliver the desired results; dan f) Negotiate performance agreements with the chosen providers."

Langkah-langkah yang diberikan oleh Osborne tersebut menjadi acuan bagi negaranegara yang mereformasi sistem birokrasi Pemerintahannya dengan landasan bahwa sistem tradisional yang digunakan memiliki pola yang sangat kaku dan lamban dalam pelaksanaan harus diubah paradigmanya menjadi perspektif kewirausahaan birokrasi.

\section{Tantangan Tol Laut}

Berbagai dampak kebijakan strategis pengembangan Tol Laut merupakan indikasi awal yang membuktikan bahwa perekonomian di daerah mulai bergerak naik. Ada pengiriman barang yang berkelanjutan dan makin besar, distrisbusi barang dan jasa lancar dan harga bahan kebutuhan pokok di masyarakat telah terkendali bahkan turun, dengan distribusi barang dan jasa yang makin cepat dan tinggi, diharapkan akan bisa menekan biaya logistik nasional, sekaligus menaikkan daya saing perekonomian lokal.

Kita tentunya berharap K/L dan Pemerintah daerah dapat terus meningkatkan sinergitas dalam mengembangkan hinterland dan kawasan industri berbasis produk unggulan daerah, serta intermoda transportasi yang dapat mendukung berkembangnya perdagangan lokal guna mengatasi masalah imbalance trade agar pengembangan Tol Laut dapat optimal tidak hanya menekan disparitas harga, namun lebih jauh dapat mengkonversikan potensi ekonomi lokal, agar memiliki nilai tambah dalam berkonstribusi memacu pembangunan inklusif, sebagai jawaban terhadap upaya meningkatkan kesejahteraan ekonomi secara merata dan berkeadilan. ${ }^{45}$

Pada saat ini angkutan laut dari Pulau Jawa ke Papua terisi penuh, namun kembali dalam keadaan kosong. ${ }^{46}$ Salah satu penyebabnya adalah karena wilayah di timur Indonesia

44 David Osborne, Reinventing Government: What A Difference A Strategy Makes, Makalah yang disampaikan pada $7^{\text {th }}$ Global Forum on Reinventing Government Building Trust in Government 26-29 June 2007, Vienna, Austria, hlm. 4.

45 Eddy Cahyono S, Tol Laut Solusi Kesejahteraan Rakyat, http://ksp.go.id/tol-laut-solusi-kesejahteraan-rakyat/ (diakses pada 20 April 2019).

46 Raldi Hendro Koestoer, et. al, Prosiding Telaah Perspektif Sosial Ekonomi Tol Laut, Jakarta: Lembaga Penerbit Program Studi Perencanaan Wilayah dan Kota Jurusan Teknik Planologi Fakultas Arsitektur Lanskap dan Teknologi Lingkungan, Universitas Trisakti, 2016, hlm. 80. 
masih memiliki konektivitas yang rendah. $\mathrm{Hal}$ ini menyebabkan biaya logistik yang dibebankan kepada komoditi menjadi tinggi, sehingga diperlukan keberpihakan dalam penyelenggaraan layanan angkutan laut dari Barat ke Timur. ${ }^{47}$

Dalam pelaksanaan program Tol Laut juga terdapat beberapa tantangan yang masih harus menjadi perhatian Pemerintah, yakni (1) infrastruktur maritim, (2) industri maritim, (3) sarana, (4) layanan, (5) SDM, (6) Teknologi Informasi dan Komunikasi (TIK), (7) regulasi, serta (8) kelembagaan. terlebih dahulu arah gerak program tersebut, jika yang didahulukan adalah pembangunan infrastruktur, maka faktor penting dalam implementasinya adalah investasi. Investasi dalam pembangunan infrastruktur pelabuhan dan moda transportasi yang padat modal dilakukan dengan model public private partnership. Pemerintah harus membuat kebijakan yang mendorong investasi sektor swasta dalam pembangunan infrastruktur.

Kualitas infrastruktur pelabuhan dan transportasi maritim dapat memfasilitasi proses perdagangan, konektivitas pengiriman

Tabel 2 Tantangan Tol Laut ${ }^{48}$

\begin{tabular}{|c|c|}
\hline $\begin{array}{l}\text { 1) Infrastruktur } \\
\text { Maritim }\end{array}$ & $\begin{array}{l}\text { - Belum memadainya dukungan infrastruktur baik dari segi kualitas dan kuantitas } \\
\text { - Belum terintegrasinya simpul transportasi dan interkoneksi pelabuhan dengan } \\
\text { hinterland (belum efektifnya peranan multimoda) }\end{array}$ \\
\hline $\begin{array}{l}\text { 2) Industri } \\
\text { Maritim }\end{array}$ & $\begin{array}{ll} & \text { Terbatasnya kemampuan daya saing industri maritim } \\
\text { - } & \text { Persebaran industri maritim yang belum merata } \\
\end{array}$ \\
\hline $\begin{array}{l}\text { 3) Sarana Tol } \\
\text { Laut }\end{array}$ & $\begin{array}{l}\text { - Keterbatasan kekuatan armada kapal nasional } \\
\text { - Kebutuhan kapal berukuran besar (akibat kondisi perairan) vs muatan dengan jumlah } \\
\text { kecil }\end{array}$ \\
\hline $\begin{array}{l}\text { 4) Layanan Tol } \\
\text { Laut }\end{array}$ & $\begin{array}{l}\text { - Lemahnya jaringan/rute laut nasional } \\
\text { - Belum adanya fokus komoditas } \\
\text { - } \quad \text { Belum optimalnya rute pelayaran (alur pelayaran dangkal dan sempit) }\end{array}$ \\
\hline 5) SDM Tol Laut & $\begin{array}{l}\text { - Rendahnya kompetensi SDM dan Manajemen } \\
\text { - Minimnya Lembaga Pendidikan dan Pelatihan Bidang Logistik dan Transportasi Laut }\end{array}$ \\
\hline 6) TIK Tol Laut & $\begin{array}{l}\text { - Belum tersedianya jaringan Teknologi Informasi dan Komunikasi yang handal } \\
\text { - Penggunaan sebagaian besar sistem manual "paper based system" dalam transaksi } \\
\text { logistik. }\end{array}$ \\
\hline $\begin{array}{l}\text { 7) Regulasi Tol } \\
\text { Laut }\end{array}$ & - Regulasi dan kebijakan masih bersifat parsial dan sektoral \\
\hline $\begin{array}{l}\text { 8) Kelembagaan } \\
\text { Tol Laut }\end{array}$ & $\begin{array}{l}\text { - Rendahnya Koordinasi Lintas Sektoral } \\
\text { - Belum ada kelembagaan yang menjadi integrator kegiatan Tol Laut }\end{array}$ \\
\hline
\end{tabular}

Sumber: Tri Achmadi, Rasionalisasi Program Tol Laut

Tantangan yang dihadapi dalam kapal dan kinerja logistik merupakan penentu pelaksanaan Tol Laut sebenarnya harus yangsangat penting dalambiaya perdagangan.

47 Direktorat Transportasi, Kementerian PPN/Bappenas, “Laporan Implementasi Tol Laut 2015”, Op.Cit., hlm 38.

48 Tri Achmadi, Rasionalisasi Program Tol Laut, Supply Chain Indonesia”, Published in Artikel Kepelabuhanan, 15 Juni 2017, hlm 4, http://supplychainindonesia.com/new/wp-content/files/SCI_-_Artikel_Rasionalisasi_ Program_Tol_Laut.pdf (diakses 19 April 2019. 
Upaya mengatasi tantangan infrastruktur, sarana, layanan, dan teknologi harus dibarengi dengan peningkatan kapasitas SDM dan pemberdayaan ekonomi lokal yang dilakukan oleh masyarakat bersama dengan Pemerintah, kesadaran masyarakat akan ketergantungan bantuan Pemerintah harus dikurangi dan mengoptimalkan bantuan saat ini untuk membangun perekonomian yang bertumpu pada ekonomi kerakyatan. Mengintegrasikan pendekatan pembangunan yang dilakukan oleh Pemerintah secara top down dan pembangunan yang diinisiasi oleh masyarakat secara bottom up akan mampu menciptakan kolaborasi yang kuat dalam menghadapi berbagai tantangan yang ada.

Pemerintah mengoptimalkan organisasinya untuk melakukan sebuah pendalaman program Tol Laut agar sasaran yang ingin dicapai tepat dan tidak salah sasaran, misalnya kementerian yang ditugasi dapat berkoordinasi dengan kementerian teknis lainnya yang berhubungan secara langsung dengan swasta maupun masyarakat pada level Daerah dan Desa.

\section{Penutup}

Berdasarkan uraian permasalahan dan analisis penerapan teori Reinventing Government David Osborne di Indonesia khususnya dalam penerapan program dan kebijakan Tol Laut, menurut tim penulis, Tol Laut telah menerapkan sebagian besar prinsip-prinsip (10 Prinsip) Reinventing Government. Untuk menjawab tantangan pengelolaan Tol Laut Pemerintah memiliki beberapa instrumen hukum untuk melakukan pengendalian agar sesuai dengan apa yang dicita-citakan untuk memeratakan pembangunan dan meningkatkan daya saing ekonomi. Meskipun tidak semua prinsip telah terpenuhi pada semua prinsip Reinventing Government tersebut, misalnya orientasi wirausaha belum terpenuhi karena ada PSO atau subsidi yang diberikan Pemerintah, dan masih belum adanya persaingan yang kompetitif di dalam penyedian pengangkutan barang di wilayah indonesia. Adanya peraturan dalam organisasi mempunyai tujuan yang baik, tetapi dalam pelaksanaan Tol Laut menyebabkan organisasi berjalan kurang melakukan pendalaman untuk merespon tuntutan inovasi karena bisa jadi melanggar aturan. Sehingga mengakibatkan keapatisan dan tidak kreatif, menurut Osborne dan Gaebler karena adanya tarik menarik konsepsi peraturan dan misi. Peraturan memang dapat mencegah penyimpangan dan korupsi, tetapi malah terjadi pemborosan atau inefisiensi. Tol Laut terlihat banyak digerakkan melalui peraturan daripada oleh misi, sehingga belum terlihat efisien, efektif dan inovatif.

Berkaitan dengan hal tersebut, Pemerintah dituntut untuk berjiwa entrepreneurship namun tetap mengedepankan kepentingan publik merupakan harapan masyarakat. Dengan demikian Strategi Reinventing Government dapat menumbuhkan sikap dan perilaku birokrat melaksanakan tugastugasnya dengan baik, birokrat yang inovatif, yang adaptif, bekerja semata-mata untuk kepentingan pelayanan publik.

Pemerintah harus melakukan pendalaman potensi sumber daya lokal khususnya wilayah timur untuk meningkatkan kapasitas muatan balik kapal dengan memfokuskan dan mengoptimalkan pemberdayaan lembaga ekonomi lokal dan masyarakat untuk terlibat dalam program Tol Laut. 
Mendorong investasi swasta dalam pembangunan infrastruktur yang padat modal dan dilakukan di bawah public private partnership. Untuk menghilangkan budaya "lambat" dan untuk efisiensi biaya Tol Laut.

\section{Daftar Pustaka}

\section{Buku}

Aurelia, Kloosterhof, Greg Schmid dkk, the consumer-driven organization strategies for transformations, (Institute for the future, 2003).

Cheema, G. Shabbir dan Dennis A. Rondinelli ed, Decentralizing Governance Emerging Concepts and Pratice, (Washington DC: Brookings Institutions, 2007).

Cullen, Ronald B. dan Donald P. Cushman, "Transitions to Competitive Government Speed, Consensus, and Performance", (New York; State University of New York).

Dernhart, Janet V. dan Robert B. Dernhart, The New Public Service: Serving, not Steering, (New York: M.E Sharpe, 2003).

Dwiyanto, Agus, Manajemen Pelayan Publik: Peduli, Inklusif, dan Kolaboratif, (Yogyakarta: Universitas Gajah Mada Press, 2015).

Ismail, Fauzi, Libatkan Rakyat dalam Pengambilan Kebijakan, (Yogyakarta: Forum LSM DIY, 2005).

Mahmudi, Manajemen Kinerja Sektor Publik, Edisi Kedua, (Yogyakarta: Sekolah Tinggi IImu Manajemen YKPN, 2010).

Osborne, David dan Ted Gaebler, Reinventing Government: How The Entrepreneural Spirit is Transforming The Public Sector, (Plume, 1993).

Putra, Fadhilla, New Public Governance, (Malang: UB Press, 2012).

Santoso, Amir dan Riza Sihbudi, Politik, Kebijakan dan Pembangunan, (Jakarta: Penerbit Dian Lestari Grafika, 1993).

Savas, E.S., "Privatization: The Key to Better Government", (New Jersey: Chatam House Publisher, 1987).

Surjadi, Pengembangan Kinerja Pelayanan Publik, (Bandung: Reifika Aditama, 2012).

Suryono, Agus, Ekonomi Politik Pembangunan, (Malang: Universitas Brawijaya, 2005).

Thoha, Miftah, Birokrasi Indonesia dalam Era Globalisasi, (Jakarta: PD Batang Gadis, 1996).

\section{Makalah/Artikel/Prosiding/Laporan/Hasil Penelitian}

Brudney, Jeffrey L. dan Deil S. Wright, Revisiting Administrative Reform in the American States: The status of Reinventing Government During the 1990s, Public Administration Review, Vol. 62 No. 3, (2002).

Brudney, Jeffrey L. dan Deil S, Wright, Privatization Across The American States: Assessing And Explaining The Scope of Contracting by State Administrative Agencies. Makalah yang disampaikan dalam Annual Meeting of the American Political Science Association (APSA) pada 30 Agustus-2 September, San Fransisco, California.

Conlan, Timothy J., Competitive Government in The United States: Policy Promotions and Divided Party, Journal of Policy and Administration, Vol. 4 No. 4, (1991).

Dewi, Dyah Andriantini Shinta, "Analisis Yuridis Pelayanan Publik Yang Baik Sebagai Sarana Mewujudkan Good Governance Dalam Konsep Welfare State", Jurnal Negara Hukum: Vol. 5, No. 2, November 2014.

Gultom, Elfrida R, "Merefungsi Pengangkutan Laut Indonesia melalui Tol Laut untuk Pembangunan Ekonomi Indonesia Timur", Fakultas Hukum Universitas Trisakti Jakarta, Juli.

Kearney, Richard C. dan Barry M. Feldman, dkk, Reinventing Government: City Manager Attitudes and Actions, Public Administration Review, Vol. 60 No. 6, (2000).

Lindsay, Cotton M., A Theory Of Gevernment Enterprise, Journal of Political Economy, Vol. 84, No. 5, 1976.

Maretich, Marta dan Jed Emerson dkk, Governing for Impact: Managing Mission-Driven Organizations Through Stages of Growth and Investment, Said Business SchoolResearch Papers (2016).

Osborne, David, Reinventing Government, Public Productivity and Management Review, Vol. 16, No. 4, 1993.

Osborne, David, Reinventing Government: What A Difference A Strategy Makes. Makalah yang disampaikan pada $7^{\text {th }}$ Global Forum on Reinventing Government Building Trust in Government 26-29 June 2007, Vienna, Austria. Rondinelli, Dennis A. dan James H. Johnson $\mathrm{Jr}$, dkk, "The Changingforces of Urban 
Economic Development: Globalization And City Competitiveness", The Journal of Policy Development and Research Vol. 3, No. 3, 1998.

Wiseman, Jane, Customer-Driven Government: How To Listen, Learn, And Leverage Data For Service Delivery Improvement, paper yang dipublikasikan oleh Data-Smart City Solutions bekerja sama dengan ASH Center For Democratic Governance And Innovation, pada tahun 2016.

\section{Internet}

Achmadi, Tri, "Rasionalisasi Program Tol Laut, Supply Chain Indonesia", published in article Kepelabuhanan, 15 Juni 2017, hlm 4 http:// supplychainindonesia.com/new/wp-content/ files/SCl_-_Artikel_Rasionalisasi_Program_ Tol_Laut.pdf (diakses 19 April 2019).

Berita Logistik dan Transportasi Indonesia, "Mengenal Pengertian, Konsep dan Manfaat Tol Laut Indonesia," https://kargo.tech/ artikel/tol-laut/ (diakses 3 Juli 2019).

Biro Kerja Sama, Hukum, dan Humas LIPI "Tidak Efektif, Tol Laut Didorong tidak hanya berdimensi Port to Port", Artikel 29 Agustus 2017, http://lipi.go.id/berita/belum-efektiftol-laut-didorong-tidak-hanya-berdimensiport-to-port/18928 (diakses 12 Agustus 2019).

Cahyono, S. Eddy, "Tol Laut Solusi Kesejahteraan Rakyat," http://ksp.go.id/tol-laut-solusikesejahteraan-rakyat/ (diakses 20 April 2019).

DH, Agung, "Pemerintah Libatkan Swasta untuk kelola Tol Laut," https://tirto.id/Pemerintahlibatkan-swasta-untuk-kelola-tol-laut-bWjS (diakses 20 April 2019).

Direktorat Transportasi Kementerian PPN/ Bappenas, "Laporan Implementasi Tol Laut 2015", http://nusantarainitiative.com/wpcontent/uploads/2016/02/150915-Buku-TolLaut-bappenas.pdf (diakses 19 April 2019).

Djumiarti, Titik, "Menggagas Strategi Reinventing Government dalam Memantapkan Kehidupan Berbangsa", diakses melalui http://eprints. undip.ac.id/19403/2/Artikel_Forum_ Nasionalisme_baru_sekali.pdf (diakses 26 Maret 2019).

Harian Ekonomi Neraca, "Tak Penuhi Target, Subsidi Tol Laut Terancam Dicabut," www. neraca.co.id/article/108160/tak-penuhitarget-subsidi-tol-laut-terancam-dicabut (diakses 20 April 2019).
Jannah, Selfie Miftahul, "Subsidi Angkutan Tol Laut Turun 50 Persen pada 2019" https://tirto. id/subsidi-angkutan-tol-laut-turun-50-persenpada-2019-deDX (diakses 30 Juli 2019).

Jannah, Selfie Miftahul "Subsidi Tol Laut Naik 33\% Jadi Rp 447 Miliar di 2018" https://finance. detik.com/berita-ekonomi-bisnis/d-3895261/ subsidi-tol-laut-naik-33-jadi-rp-447-miliardi-2018 (diakses 30 Juli 2019).

Rakhmat, Muhamad, "Hukum Administrasi Negara Indonesia," https://jurnal.unma.ac.id/ index.php/RBJ/article/download/531/495 (diakses 10 Desember 2018).

Wijaya, Eka, "Program "Tol Laut" Presiden Telah Dijalankan, Disparitas Harga Dihilangkan," http://setkab.go.id/program-tol-lautpresiden-telah-dijalankan-disparitas-hargadihilangkan/ (diakses 20 April 2018).

\section{Peraturan Perundang-Undangan}

Undang-Undang Nomor 25 Tahun 2009 tentang Pelayanan Publik.

Peraturan Presiden Nomor 71 Tahun 2015 tentang Penetapan dan Penyimpanan Barang Kebutuhan Pokok dan Barang Penting.

Peraturan Presiden Nomor 106 Tahun 2015 tentang Penyelenggaraan Kewajiban Pelayanan Publik Untuk Angkutan Barang di Laut.

Peraturan Presiden Nomor 70 Tahun 2017 tentang Penyelenggaraan Kewajiban Pelayanan Publik untuk Angkutan Barang Dari dan ke Daerah Tertinggal, Terpencil, Terluar dan Perbatasan.

Peraturan Menteri Perhubungan Nomor PM 4 Tahun 2018 tentang Penyelenggaraan Kewajiban Pelayanan Publik untuk Angkutan Barang Laut.

Peraturan Menteri Perhubungan Nomor PM 29 Tahun 2018 tentang Tarif Angkutan Barang di Laut Untuk Melaksanakan Kewajiban Pelayanan Publik (Public Service Obligation). 